\title{
Centaurea rupestris L.: Cytogenetics, Essential Oil Chemistry and Biological Activity
}

\author{
Ivana Carev, ${ }^{1, *}$ Ana Maravić, ${ }^{2}$ Mejra Bektašević, ${ }^{3}$ Mirko Ruščić, ${ }^{2}$ Sonja Siljak-Yakovlev, ${ }^{4}$ Olivera Politeo ${ }^{1}$
}

\footnotetext{
1 Department of Biochemistry, Faculty of Chemistry and Technology, University of Split, Ruđera Boškovića 35, HR-21000 Split, Croatia

2 Department of Biology, Faculty of Science, University of Split, Ruđera Boškovića 33, HR-21000 Split, Croatia

3 Biotechnical Faculty, University of Bihać, Luke Marjanovića bb, BA-77000 Bihać, Bosnia and Herzegovina

${ }^{4}$ Ecologie Systématique Evolution, Univ. Paris-Sud, CNRS, AgroParisTech, Université Paris-Saclay, FR-91400, Orsay cedex, France

* Corresponding author's e-mail address: ivana.carev@ktf-split.hr
}

RECEIVED: August 18, 2017 * REVISED: December 18, 2017 * ACCEPTED: January 08, 2018

\begin{abstract}
Centaurea species are used in eastern Mediterranean ethnopharmacology due to variety of bioactive compounds they comprise. Aim of this work was to characterize the Centaurea rupestris L. hydrodistilled essential oil chemical composition and test its biological activity: antimicrobial effect, antioxidant potential and inhibition of cholinesterases. Plant material authentication was by chromosome number counting and genome size assessment with the flow cytometry. Hydrodistilled essential oils were characterized using gas chromatography/mass spectrometry technique GC-MS and GC-FID. The antimicrobial effect was tested using disk diffusion and microdilution methods, antioxidant potential was tested with DPPH and FRAP methods and cholinesterases inhibition was tested with Ellman method. Genome size for $C$. rupestris species: sample A presented 2C=3.60 (0.10) pg and sample B 2C=3.62 (0.08) pg. The chromosome number was $2 \mathrm{n}=20$ for both samples. The main essential oil constituents in isolated sample A oil, detected with GC-MS and GC-FID were: germacrene D (24.3\%), heptacosane (14.4\%), phytol (6.7\%), $\beta$-caryophyllene (5.0\%) and pentacosane (4.5\%). Sample B essential oil had the main constituents: hexadecanoic acid (18.7 \%), heptacosane (13.8\%), $\alpha$-linolenic acid (11.8\%), nonacosane (7.8\%) and germacrene D (5.4 \%). Both samples of oil showed broad spectrum antimicrobial effect with good activity against emerging Gram-positive and Gram-negative opportunistic pathogens and pathogenic fungi which indicates the pharmaceutical potential of the C. rupestris essential oil.
\end{abstract}

Keywords: antimicrobial activity, antioxidant potential, cholinesterases inhibition, essential oil, GC/MS, genome size.

\section{INTRODUCTION}

D UE to an antibiotic resistance, around 700000 people worldwide are each year threatened and killed by drug-resistant microbes. The World Health Organization (WHO) released a list of 12 drugs - resistant bacteria or bacterial families for which new antimicrobial agents are needed. This presents the top priority in this area of science. ${ }^{[1]}$

Interests in natural products as a source of identification and development of antibacterial agents have historically been of crucial importance. Recently interests in natural compounds have increased due to rapid development of resistant bacterial strains. This forced reevaluation of natural products as a source of novel chemical skeletons with antibacterial activity for elaboration in drug development. ${ }^{[2]}$
In this study, we aim to investigate the antimicrobial activity of Centaurea rupestris L. essential oil (EO) targeting the nosocomial pathogens included in the notorious multidrug resistant 'ESKAPE' group (Enterococcus spp., Staphylococcus aureus, Klebsiella spp., Acinetobacter baumannii, Pseudomonas aeruginosa and Enterobacter spp.) that effectively evade the therapeutic effects of antibacterial drugs. ${ }^{[3]}$ We investigated an antimicrobial potential of $C$. rupestris EO on most of the microbes listed where new antimicrobial agents are urgently needed. ${ }^{[1]}$ We also aim to study the antioxidant potential and inhibition of cholinesterase of these EOs to evaluate this aspect of biological activity of C. rupestris essential oil.

Centaurea species are well known for their medicinal properties in eastern Mediterranean ethnopharmacology (1). ${ }^{[4]}$ Centaurea genus, Asteraceae 
family, is widespread in worldwide area comprising around 400 up to 700 species, of which around 80 with 27 endemics are present in Croatia. ${ }^{[5]}$ Centaurea rupestris L., belongs to a Hyaleoloma (Acrocentron) section in botanical systematic, grow on dried rocky grasslands in sub-Mediterranean vegetation areas. ${ }^{[5]}$ Essential oil (EO) composition is investigated in only four species from Hyaleoloma (Acrocentron) section of Centaurea genus. ${ }^{[6-8]}$ Essential oil may be source of chemical compounds that are good antioxidants and inhibitors of cholinesterases, enzymes important in Alzheimer's disease. ${ }^{[9,10]}$ Essential oils are consisted of a small lipophilic molecules that can easily cross brain-blood barrier and serve as a good therapeutic agents. ${ }^{[11,12]}$ There is only three Centaurea species investigated on EO inhibition of cholinesterases. ${ }^{[13]}$ Essential oil of only one Centaurea was investigated for antioxidant activity. ${ }^{[14]}$ Good antimicrobial activity was previously found in some Centaurea species EO. ${ }^{[10,15-22]}$

Due to a need for an authentic plant material, evaluated both with a botanist expertise and molecular methods, the genome size and chromosome number were assessed. In botanical authentication of plant material, together with morphological traits, a genome size, the amount of DNA in the un-replicated haploid nucleus of an organism, are important biological traits used for plant characterization. ${ }^{\text {[23-25] }}$

To the best of our knowledge this is the first report on $C$. rupestris biological activity of EO. The evaluation of chemical composition of $C$. rupestris essential oil and its microbiological validation data will hopefully assist in the identification of promising chemical structures towards life-threatening microbes.

\section{EXPERIMENTAL SECTION}

\section{Plant Material}

Centaurea rupestris L., Asteracea, barbed knapweed herbs and flowers were collected during the same period in the summer from natural populations in Croatia: Kozjak hill, Malačka locality, (sample A) and on the island of Krk (sample B) and identified by a botanist dr. sc. Mirko Ruščić. Plants were collected during flowering period in a full blooming phase. Voucher specimens of plant materials used for this study with date of collection have been deposited in herbarium at the Department of Biochemistry, Faculty of Chemistry and Technology, Split, Croatia, under a name Cent_rup_Kozjak_6 and Cent_rup_Krk_14 with the date and GPS location of collection. The leaves and seeds were used for cytogenetic assessment and plant authentication. Aerial parts, herbs and few flowers were used for EO extraction.

\section{Chromosome Number and Genome Size Evaluation}

The leaves and seeds were used for genome size assessment by flow cytometry. Leaves and an internal standard were chopped together using a one razor blade in a Petri dish with $600 \mu \mathrm{L}$ of cold Galbraith buffer supplemented with $1 \%$ polyvinylpyrrolidone 10,000 and 50 $\mu \mathrm{g} / \mathrm{mL}$ RNAse A (Sigma Chemical Co. St. Louis, USA). ${ }^{[26]}$ Solanum lycopersicum L. "Montfavet 63/5 (2C=1.99 pg) was used as internal standard. ${ }^{[27]}$ In order to remove large tissue debris and fragments, the nuclei suspension was filtered through nylon mesh, with $50 \mu \mathrm{m}$ size of pore and stained with $50 \mu \mathrm{g} / \mathrm{mL}$ propidium iodide (Sigma Chemical Co. St. Louis, USA). At least 5 individuals with 5000 to 10000 analyzed nuclei were measured to obtain the mean DNA content. The $2 C$ DNA value was calculated using the linear relationship between the known internal standard and the fluorescent signals from stained nuclei of the tested specimen. Flow cytometry was performed on CyFlow SL3, Partec, Munster, Germany. Chromosome number was determined from germinated seedlings using classical Feulgen technique.

\section{Essential oil extraction, gas chromatography (GC) and gas chromatography-mass spectrometry (GC-MS) analyses} Air-dried aerial parts of plants were hydro-distilled using Clavenger apparatus for 3 hours. Isolated essential oil was stored in a sealed vial, under $-20^{\circ} \mathrm{C}$ till use. The gas chromatography analysis of EO was performed using Varian Inc. gas chromatograph, model 3900, Lake Forest, CA, USA equipped with a flame ionization detector and mass detector, model $2100 \mathrm{~T}$, with a non-polar capillary column VF-5MS (30 m $\times 0.25 \mathrm{~mm}$ i.d.; coating thickness $0.25 \mu \mathrm{m}$ ). Temperature program for VF-5MS column was: $60{ }^{\circ} \mathrm{C}$ isothermal for $3 \mathrm{~min}$, than increased to $246{ }^{\circ} \mathrm{C}$ at a rate of

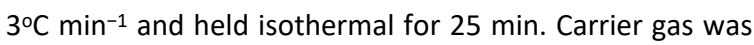
helium at flow rate $1 \mathrm{~mL} \mathrm{~min}{ }^{-1}$, injector temperature was $250^{\circ} \mathrm{C}$, injected volume $1 \mu \mathrm{L}$; split ratio of 1:20; FID detector temperature was $300{ }^{\circ} \mathrm{C}$. Mass spectrometer ionization voltage was $70 \mathrm{eV}$, mass scan range: $40-350$ mass units and ion source temperature was $200^{\circ} \mathrm{C}$. Identification of EO chemical composition was based on comparison of compound mass spectra with databases (Wiley 7 library Wiley, New York, NY, USA; Adams 2007) and comparison of their retention indices (relative to series of $n$-alkanes $C_{9-}$ $\mathrm{C}_{40}$ ) with internal database retention indices and literature retention indices using NIST2002 (National Institute of Standards and Technology, Gaithersburg, MD, USA).[28,29] The internal database of compounds was created during previous analyses from authentic compounds obtained commercially and from more than thousand EO obtained during our previous studies. The percentages of components were calculated as mean values from the GC and GC-MS peak areas. 


\section{Biological Activities of Essential Oil}

Determination of essential oil antioxidant capacity Antioxidant capacity of $C$. rupestris essential oils in concentration of $1 \mathrm{~g} / \mathrm{L}(0,048 \mathrm{~g} / \mathrm{L}$ in reaction system) were tested using method 2,2-Diphenyl-1-picrylhydrazyl (DPPH) radical (Sigma-Aldrich, Steinheim) scavenging method according to a method of Brand-Williams (1995) and ferric reducing power assay (FRAP) using the method of Benzie and Strain (1996) for EO's in concentration of $1 \mathrm{~g} / \mathrm{L}(0,033$ $\mathrm{g} / \mathrm{L}$ in reaction system). ${ }^{[30,31]}$ Inhibition of the DPPH radical by the samples was calculated according to formula: \% inhibition $=\left(\left(A_{0}-A_{\text {sample }}\right) / A_{0}\right) \times 100$ where $A_{0}$ is absorbance of the DPPH ethanolic solution measured at the beginning where $t=0$ min and $A_{\text {sample }}$ is absorbance of the sample measured after $60 \mathrm{~min}$. Reducing power of the EO was expressed in $\mathrm{mmol} \mathrm{Fe}^{2+} / \mathrm{L}$ and calculated comparing the absorbance of samples with absorbance of reaction given by solution of $\mathrm{Fe}^{2+}$ ions of known concentration. The measurements were performed on microplate reader „Sunrise“(Tecan GmbH, Austria).

\section{Determination of Acetylcholinesterase / Butyrylcholinesterase inhibition}

Determination of Acetylcholinesterase (AChE) / Butyrylcholinesterase (BChE) inhibition was performed using Ellman's method (1961) with essential oils in concentration of $1 \mathrm{~g} / \mathrm{L}\left(0,045 \mathrm{~g} / \mathrm{L}\right.$ in reaction system). ${ }^{[32]}$ Acetylcholineesterase (E.C. 3.1.1.7) type V-S from electric eel (SigmaAldrich, Steinheim), Butirylcholine esterase (E.C. 3.1.1.8) from horse serum (Sigma-Aldrich, Steinheim) were used; acetylthiocholine iodide (ATChI), (Sigma-Aldrich, Steinheim), and butyrylthiocholine iodine (BTChl), (SigmaAldrich, Steinheim), were used as substrates. The percent of the inhibition was calculated according to formula: $\%$ inhibition $=(((\mathrm{E}-\mathrm{BE})-(\mathrm{S}-\mathrm{BS})) /(\mathrm{E}-\mathrm{Bs}))) \times 100$ where $\mathrm{E}$ presents absorbance of measurements of enzyme activity without sample, $\mathrm{S}$ is an absorbance of sample activity with enzyme, $\mathrm{BE}$ is "blank" measurement for without AChE / BChE and BS is sample "blank" measurement for sample without enzyme. Absorbance was taken after 6 minutes of reaction and measurements were performed in triplicate and the data present mean value. The data was evaluated in comparison to a tacrine (Sigma-Aldrich, Steinheim) and eserine (Sigma-Aldrich, Steinheim), inhibitors of both enzymes. The measurements were performed on microplate reader "Sunrise“(Tecan GmbH, Austria).

\section{Determination of antimicrobial activity of essential oil}

The antimicrobial screening of the EO dissolved in DMSO was carried out by the disc-diffusion and the broth microdilution assays against laboratory control strains from the American Type Culture Collection (ATCC) (Rockville, USA) and the clinical strains from the Laboratory of
Microbiology, Department of Biology, Faculty of Science, University of Split, Croatia (FNSST), according to the procedures described previously. ${ }^{[22]}$ The microdilution assays for testing bacteria, yeasts and filamentous fungi were carried out by the guidelines of the Clinical Laboratory Standards Institute, with the exception that broth dilution antifungal susceptibility testing was conducted in Sabouraud dextrose broth (SDB, Biolife, Italy). ${ }^{[33-35]}$

\section{RESULTS AND DISCUSSION}

Plant material for both samples of EO was collected during the same period from two different localities in Croatia. The authentication of collected plant material was determined with botanist expertise using morphological traits of the $C$. rupestris, together with method of determining the chromosome number and genome size.

Genome size was assessed using flow cytometry and was expressed as $2 \mathrm{C}$ DNA (tstandard deviation) in picograms $(\mathrm{pg})$. Population named sample $A$ showed genome size of $3.60( \pm 0.10) \mathrm{pg}$; while sample B showed genome size of $3.62( \pm 0.08) \mathrm{pg}$. Both samples possessed $2 n$ $=20$ chromosomes. These results are consistent and in compliance with previously reported genome size and chromosome number for this species approving that plant material used for the both samples was authentic $C$. rupestris (Siljak Yakovlev, 2005). ${ }^{[25]}$

Centaurea rupestris EO from two different localities was investigated on the chemical composition using GC/MS and results are presented in Table 1.

Essential oil of $C$. rupestris in sample $A$ had 35 and in sample B had 30 different chemical compounds. Terpene compounds were present in an A sample $(55.1 \%)$ in higher amount than non-terpene compounds (40.0\%), while in sample B terpenes were present in smaller amount (29.3\%) than non-terpene compounds (63.5\%). Dominant components of EO in sample A were: germacrene D (24.3\%), heptacosane (14.4\%), phytol (6.7\%), $\beta$-caryophyllene (5.0 $\%)$ and pentacosane (4.5\%). Dominant components of EO in sample B were: hexadecanoic acid (18.7\%), heptacosane (13.8\%), $\alpha$-linolenic acid (11.8\%), nonacosane (7.8\%) and germacrene $D(5.4 \%)$. It is important to notice a different composition of both studied EO, although they are from the same species. It should be noticed that plant material was collected during the same period, but on a different localities. The composition of essential oil can vary depending on the microclimate conditions present on different localities. ${ }^{[36]}$

The biological activity of essential oil was tested on antioxidant potential, inhibition of cholinesterase and antimicrobial activity and the results are presented in Table 2 .

The antioxidant activity of essential oils of $C$. rupestris were tested on antioxidant potential using FRAP 
Table 1. Chemical composition and chemical class distribution of the essential oil of Centaurea rupestris

\begin{tabular}{|c|c|c|c|c|c|}
\hline & Compound name & $\begin{array}{c}\text { Sample A C. rupestris } \\
\text { Kozjak hill, Malačka (6) }\end{array}$ & $\begin{array}{c}\text { Sample B C. rupestris } \\
\text { island of Krk (14) }\end{array}$ & $\mathrm{KI}$ & Identification \\
\hline & Terpene compounds & $55.1 \%$ & $29.3 \%$ & & \\
\hline & Nonoxigenated monoterpenes & - & $\operatorname{tr}$ & & \\
\hline \multirow[t]{2}{*}{1.} & $\alpha$-pinene & - & $\operatorname{tr}$ & 930 & $\mathrm{KI}, \mathrm{MS}$ \\
\hline & Nonoxigenated sesquiterpenes & 36.4 & 16.2 & & \\
\hline 2. & Bicycloelemene & 0.6 & 0.6 & 1328 & $\mathrm{KI}, \mathrm{MS}$ \\
\hline 3. & $\beta$-ylangene & - & 0.3 & 1362 & $\mathrm{KI}, \mathrm{MS}$ \\
\hline 4. & $\beta$-elemene & - & 0.4 & 1391 & $\mathrm{KI}, \mathrm{MS}$ \\
\hline 5. & $\beta$-caryophyllene & 5.0 & 4.1 & 1416 & $\mathrm{KI}, \mathrm{MS}$ \\
\hline 6. & $\alpha$-calarene & - & 1.1 & 1426 & $\mathrm{KI}, \mathrm{MS}$ \\
\hline 7. & $\beta$-copaene & 1.4 & - & 1429 & $\mathrm{KI}, \mathrm{MS}$ \\
\hline 8. & $\gamma$-elemene & - & 0.4 & 1437 & $\mathrm{KI}, \mathrm{MS}$ \\
\hline 9. & cis- $\beta$-farnesene & 0.6 & 0.5 & 1442 & $\mathrm{KI}, \mathrm{MS}$ \\
\hline 10. & $\beta$-calarene & 1.3 & 1.5 & 1451 & $\mathrm{KI}, \mathrm{MS}$ \\
\hline 11. & $\alpha$-hummulene & 1.8 & - & 1456 & $\mathrm{KI}, \mathrm{MS}$ \\
\hline 12. & $y$-muurolene & 0.1 & - & 1475 & $\mathrm{KI}, \mathrm{MS}$ \\
\hline 13. & Germacrene D & 24.3 & 5.4 & 1482 & $\mathrm{KI}, \mathrm{MS}$ \\
\hline 14. & Pachulene & - & 0.5 & 1488 & $\mathrm{KI}, \mathrm{MS}$ \\
\hline 15. & Bicyclogermacrene & 0.6 & 0.9 & 1495 & $\mathrm{KI}, \mathrm{MS}$ \\
\hline 16. & Germacrene A & 0.3 & - & 1507 & $\mathrm{KI}, \mathrm{MS}$ \\
\hline \multirow[t]{2}{*}{17.} & $y$-cadinene & 0.4 & 0.5 & 1519 & $\mathrm{KI}, \mathrm{MS}$ \\
\hline & Oxigenated sesquiterpenes & 12.0 & 10.5 & & \\
\hline 18. & Spathulenol & 2.8 & 3.9 & 1568 & $\mathrm{KI}, \mathrm{MS}$ \\
\hline 19. & Hummulene-epoxide II & 0.4 & - & 1608 & $\mathrm{KI}, \mathrm{MS}$ \\
\hline 20. & Isospathulenol & 1.1 & - & 1635 & $\mathrm{KI}, \mathrm{MS}$ \\
\hline 21. & $\tau$-muurolol & 0.6 & - & 1652 & $\mathrm{KI}, \mathrm{MS}$ \\
\hline 22. & 7-epi- $\alpha$-eudesmol & 1.8 & - & 1660 & $\mathrm{KI}, \mathrm{MS}$ \\
\hline 23. & Aromadendrene oxide & 1.1 & 2.5 & 1671 & $\mathrm{KI}, \mathrm{MS}$ \\
\hline 24. & $\alpha$-bisabolol & 3.2 & 4.1 & 1684 & $\mathrm{KI}, \mathrm{MS}$ \\
\hline \multirow[t]{2}{*}{25.} & $\alpha$-ciperone & 1.0 & - & 1762 & $\mathrm{KI}, \mathrm{MS}$ \\
\hline & Oxigenated diterpene & 6.7 & 2.6 & & \\
\hline \multirow[t]{3}{*}{26.} & Phytol & 6.7 & 2.6 & 2115 & $\mathrm{KI}, \mathrm{MS}$ \\
\hline & Non-terpene compounds & $40.0 \%$ & $63.5 \%$ & & \\
\hline & Hydrocarbons & 30.1 & 28.0 & & \\
\hline 27. & Octadecane & 0.4 & - & 1800 & $\mathrm{KI}, \mathrm{MS}$ \\
\hline 28. & Tricosane & 2.0 & 1.1 & 2300 & $\mathrm{KI}, \mathrm{MS}$ \\
\hline 29. & Tetracosane & 1.7 & 1.0 & 2400 & $\mathrm{KI}, \mathrm{MS}$ \\
\hline 30. & Pentacosane & 4.5 & 2.5 & 2500 & $\mathrm{KI}, \mathrm{MS}$ \\
\hline 31. & Hexacosane & 2.4 & 0.9 & 2600 & $\mathrm{KI}, \mathrm{MS}$ \\
\hline 32. & Heptacosane & 14.4 & 13.8 & 2700 & $\mathrm{KI}, \mathrm{MS}$ \\
\hline 33. & Octacosane & 0.6 & 0.9 & 2800 & $\mathrm{KI}, \mathrm{MS}$ \\
\hline \multirow[t]{2}{*}{34.} & Nonacosane & 4.1 & 7.8 & 2900 & $\mathrm{KI}, \mathrm{MS}$ \\
\hline & Alchohols & $\operatorname{tr}$ & - & & \\
\hline \multirow[t]{2}{*}{35.} & Octanol & $\operatorname{Tr}$ & - & 1068 & $\mathrm{KI}, \mathrm{MS}$ \\
\hline & $\begin{array}{ll}\text { Aldehides } \\
\end{array}$ & $\operatorname{tr}$ & 0.6 & & \\
\hline 36. & 2-phenylacetaldehide & $\operatorname{Tr}$ & 0.3 & 1045 & $\mathrm{KI}, \mathrm{MS}$ \\
\hline \multirow[t]{2}{*}{37.} & Nonanal & - & 0.3 & 1102 & $\mathrm{KI}, \mathrm{MS}$ \\
\hline & Ketones & 4.6 & 3.3 & & \\
\hline 38. & 3-oxo- $\beta$-Ionone & - & 1.4 & 1671 & $\mathrm{KI}, \mathrm{MS}$ \\
\hline \multirow[t]{2}{*}{39.} & $\begin{array}{l}\text { 6,10,14-trimethyl 2- } \\
\text { Pentadecanone }\end{array}$ & - & - & 1850 & $\mathrm{KI}, \mathrm{MS}$ \\
\hline & Acids & 5.3 & 31.6 & & \\
\hline 40. & Hexadecanoic acid & 3.2 & 18.7 & 1982 & $\mathrm{KI}, \mathrm{MS}$ \\
\hline 41. & $\alpha$-linolenic acid & 1.7 & 11.8 & 2169 & $\mathrm{KI}, \mathrm{MS}$ \\
\hline \multirow[t]{2}{*}{42.} & Octadecanoic acid & 0.4 & 1.1 & 2198 & $\mathrm{KI}, \mathrm{MS}$ \\
\hline & Esters & - & - & & $\mathrm{KI}, \mathrm{MS}$ \\
\hline 43. & Metyl-tetradecanoate & 1.7 & - & 1727 & $\mathrm{KI}, \mathrm{MS}$ \\
\hline \multirow[t]{2}{*}{44.} & Benzyl-benzoate & 2.9 & 1.9 & 1765 & $\mathrm{KI}, \mathrm{MS}$ \\
\hline & TOTAL & 95.1 & 97.8 & & \\
\hline
\end{tabular}

Note: $\mathrm{KI}=$ Kovat's index determined on a VF-5MS column using the homologous series of $n$-alkanes $\left(C_{9}-C_{40}\right) ; \operatorname{tr}=\operatorname{traces}(<0.1 \%) ;$ MS $=$ mass spectra. 


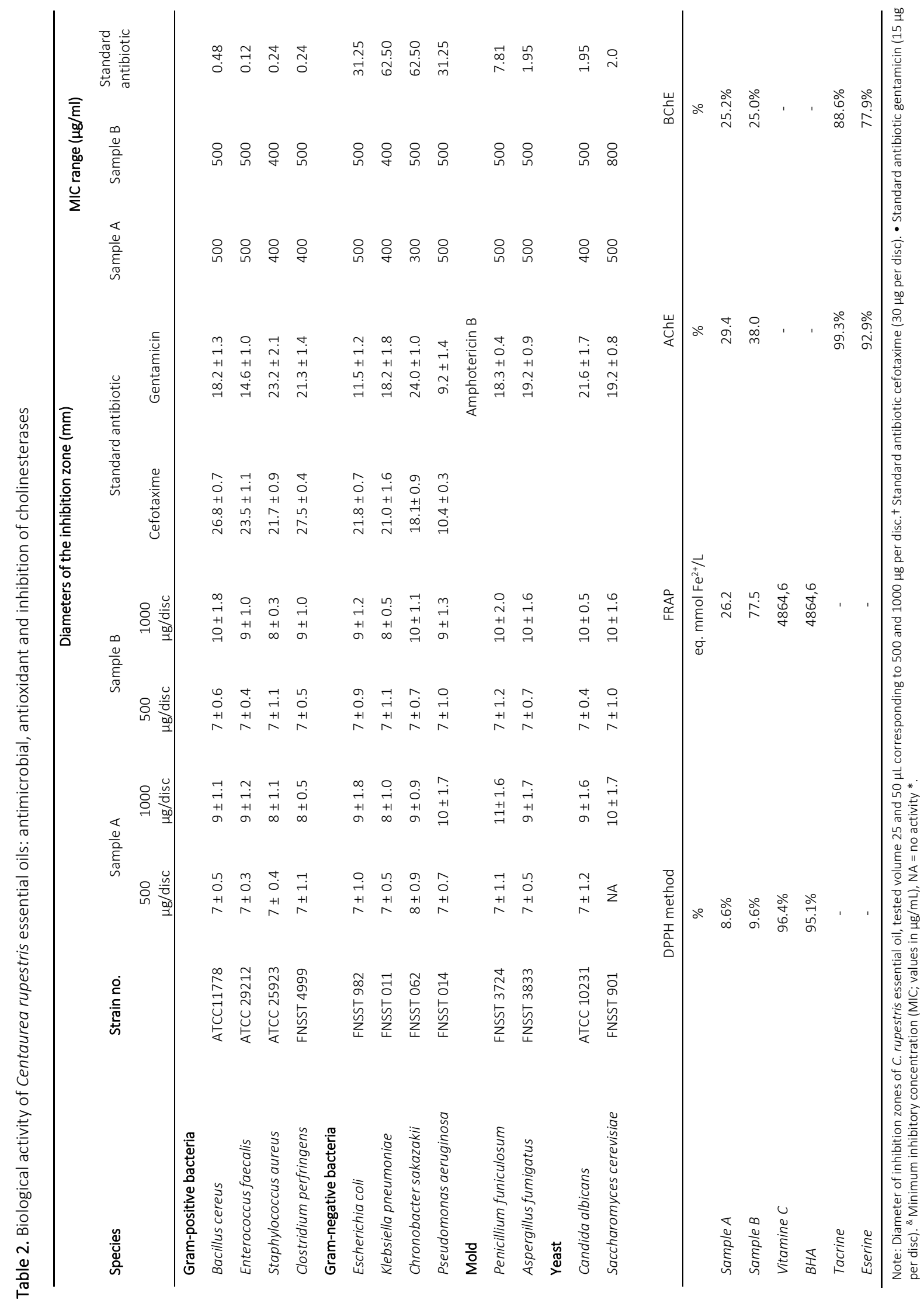

DOI: $10.5562 /$ cca3205 
and DPPH methods. The inhibition of DPPH reaction was $8.6 \%$ and $9.6 \%$ for sample $A$ and $B$, while the FRAP potential expressed as ekv. mmol $\mathrm{Fe}^{2+} / \mathrm{L}$ was 26.2 and 77.5 respectively. Comparing to the standards used in both methods (Table 2), both Eos tested with both FRAP and DPPH methods showed no antioxidant activity. The absence of antioxidant potential can be connected with a chemical compounds found in both essential oils. None of the listed chemicals belong to groups of chemical compounds from nature already known for their good antioxidant activity like phenolic compounds or monoterpenoides. ${ }^{[9]}$

Inhibition of cholinesterases with essential oil was tested using Ellman method. Acetylcholinesterase inhibition was $29.4 \%$ and $38.0 \%$ for sample $A$ and $B$, while the butyrylcholinesterase inhibition was $25.2 \%$ and $25.0 \%$ for sample A and B. Both tested EOs showed low to moderate anticholinesterase activity, where inhibition of $\mathrm{AChE}$ was better than inhibition of BChE. Previously tested Centaurea species EO in stock solution concentration of 0.2 $\mathrm{g} / \mathrm{L}$ showed inhibition of $44.90 \%$ up to $63.45 \%$ for AChE and $51.59 \%$ up to $65.83 \%$ for BChE. ${ }^{[13]}$ The presented Centaurea EO did not contain already known good inhibitors of cholinesterases. ${ }^{[11]}$ Of all detected $C$. rupestris volatile compounds only $\beta$-caryophyllene and caryophyllene oxide were tested on cholinesterases inhibition and showed low activity. ${ }^{[37,38]} \mathrm{C}$. rupestris EO showed better cholinesterase inhibition potential than these two pure compounds. ${ }^{[37]}$ It could be concluded that there is synergistic effect among essential oil constituents.

This study is first report of $C$. rupestris EO antimicrobial activity. Antimicrobial activity of essential oils was tested using disc diffusion and microdilution methods, results are presented in Table 2. Both EO showed broad spectrum antimicrobial effect with moderate to good activity against emerging Gram-positive and Gram-negative opportunistic pathogens and pathogenic fungi used in this study. We targeted pathogens responsible for a variety of clinical syndromes, from skin and wound infections, gastroenteritis; to life-threatening conditions such as septicemia and meningitis. The MIC values obtained for both samples against bacterial and fungal strains were similar, ranging mainly from 400 up to $500 \mu \mathrm{g} / \mathrm{mL}$. However, somewhat elevated MIC values were observed when yeasts Candida albicans and Saccharomyces cerevisiae were tested with sample $B$ in comparison to sample A (500 and $800 \mu \mathrm{g} / \mathrm{mL}$ ), respectively. There was no significant difference in antimicrobial activity of both EO when comparing Gram-negative and Gram-positive bacteria. Notably, the EO had the most potent activity (MIC $300 \mu \mathrm{g} / \mathrm{mL}$ ) against Cronobacter sakazakii, an emerging pathogen recovered from various food products, including powdered infant formula and a causative agent of severe neonatal infections out of which meningitis in particular. ${ }^{[39]}$ Pseudomonas aeruginosa, one of the leading nosocomial and community-acquired pathogen known by its acquisition of resistance to various classes of antibiotics was inhibited at $400 \mu \mathrm{g} / \mathrm{mL}{ }^{[3]}$ In addition, the EO was found to be active against common food pathogens, Grampositive bacteria Staphylococcus aureus and Clostridium perfringens.

The observed broad-spectrum of EO antimicrobial activity in our previous work was related to a high amount of sesquiterpene germacrene D present in Centaurea species. ${ }^{[22]}$ In this study the EO with higher amount of germacrene $D$ had slightly better antimicrobial activity on some pathogens. The germacrene $D$ and its antimicrobial potential will be subject of our further studies.

Previously tested essential oil of $O$. vulgare, with germacrene $\mathrm{D}, \quad \beta$-caryophyllene and spathulenol as dominant components, also showed great antimicrobial potential. ${ }^{[40]}$ Some other studies connected structural and pharmacological properties of spathulenol and $\alpha$-bisabolol with a good antimicrobial activity. ${ }^{[41,42]}$ Some other potential candidate responsible for good antimicrobial potential, found as a component in these EO's, was diterpene alcohol phytol. ${ }^{[43]}$

Non terpene compounds such as heptacosane and nonacosane, as well as fatty acid like hexadecanoic acid found in these EO's as major components, were previously recognized as responsible for a good antimicrobial activity as well. ${ }^{[44-46]}$

It is shown that all of the dominant components in both EO's were previously connected with a good antimicrobial activity of essential oils. Essential oils are mixtures of chemical compounds that might show synergistic effect when they show biological activity. ${ }^{\left[{ }^{[0]}\right.}$ As both studied essential oils have different composition and different dominant compounds it is hard to point out which specific chemical compound or even a group of chemical compounds is responsible for antimicrobial activity. Therefore, further studies are necessary to detect the specific compound responsible for antimicrobial activity.

\section{CONCLUSION}

Essential oil of two tested samples of $C$. rupestris showed broad spectrum antimicrobial effect with good activity against emerging Gram-positive and Gram-negative opportunistic pathogens and pathogenic fungi which indicates the pharmaceutical potential of the $C$. rupestris essential oil. Dominant components of essential oils were: germacrene $\mathrm{D}$, heptacosane, phytol, $\beta$-caryophyllene, pentacosane; nonacosane, hexadecanoic acid, $\alpha$-linolenic acid, caryophyllene oxide and $\alpha$-bisabolol. The plant material was authentically approved with genome size of 
$2 \mathrm{C}=3.60-3.62 \mathrm{pg}$, and chromosome number of $2 n=20$. Both tested EO's showed low antioxidant activity and moderate inhibition of both cholinesterases.

Acknowledgment. We would like to thank Spencer C. Brown for his assistance in cytometry at the Imagerie-Gif, Plateforme de Cytométrie CNRS- I2BC, Gif-sur-Yvette, France. This work was funded in part by Croatian Science Foundation under the project IP-2014-09-6897. This work was partially result of the project "Chemical and biological observation of selected plant species of Croatia" financially supported by the Ambassade de France en Croatie, Service de Cooperation et d'Action Culturelle; Agency for Mobility and EU Programmes, Centre National de la Recherche Scientifique de France (CNRS) and Croatian Ministry of Science, Education and Sport.

\section{REFERENCES}

[1] C. Willyard, Nature, 2017, 15, 543.

[2] M. G. Moloney, G. Mark, Trends Pharmacol. Sci. 2016, 37, 689.

[3] H. W. Boucher, G. H. Talbot, J. S. Bradley, J. E. Edwards, D. Gilbert, L. B. Rice, M. Scheld, B. Spelberg, J. Bartlett, Clin. Infect Dis. 2009, 1, 48.

[4] U. Cakilcioglu, I. Turkoglu, J. Ethnopharmacol. 2010, $1,132$.

[5] T. Nikolić, Sistemska botanika - raznolikost $i$ evolucija biljnog svijeta, Zagreb: Alfa d.d., 2013.

[6] G. Flamini, K. Ertugrul, P. L. Cioni, I. Morelli, H. Dural, Y. Bagci, Biochem. Syst. Ecol. 2002, 30, 953.

[7] A. Tava, S. Esposti, M. Boracchia, L. Viegi, J. Essent. Oil Res. 2010, 22, 223.

[8] B. S. Erel, B. Demirci, S. Demir, C. Karaalp, K. H. C. Baser, S. B. Erel, J. Essent. Oil Res. 2013, 25, 79.

[9] F. Bakkali, S. Averbeck, D. Averbeck, M. Idaomar, Food Chem. Toxico, 2008, 46, 446.

[10] O. Politeo, M. Skocibusic, I. Carev, F. Burcul, I. Jerkovic, M. Sarolic, Nat Prod Commun. 2012, 7, 1087.

[11] P. J. Houghton, Y. Ren, M. J. Howes, Nat. Prod. Rep. 2006, 23,181.

[12] M. Jukic, O. Politeo, M. Maksimovic, M. Milos, Phytother. Res. 2007, 21, 259.

[13] A. Ertas, A.C. Goren, M. Boga, S. Demirci, U. Kolak, J. Essent. Oil Bear Plants 2014, 17, 922.

[14] R. A. A. Mothana, S. A. A. Abdo, S. Hasson, F. M. N. Althawab, S. A. Z. Alaghbari, U. Lindequist, EvidenceBased Complement Altern Med, Oxford University Press, 2010, 7, 323.

[15] N. Yayli, A. Yaşar, C. Güleç, A. Usta, S. Kolaylı, K. Coşkunçelebi, Phytochem. 2005, 66, 1741.

[16] N. Yayli, A. Yasar, C. Albay, Y. Asamaz, K.
Coskuncelebi, S. Karaoglu, Pharm. Biol. 2009, 47, 7.

[17] S. Djeddi, M. Sokovic, H. Skaltsa, S. Djeddi, J. Essent. Oil Bear Plants 2011, 14, 658.

[18] N. Kahriman, S. Alpay, N. Karaoğlu, N. Yayli, G. Tosun, Y. Iskender, Nat. Prod. Res. 2012, 26, 703.

[19] Y. Bulent Kose, G. Iscan, B. Demirci, K. H. Baser, S. Celik, Y. Bülent Köse, Fitoterapia 2007, 78, 253.

[20] F. Senatore, C. Formisano, A. Raio, G. Bellone, M. Bruno, Nat. Prod. Res. 2008, 22, 825.

[21] T. Milosevic, C. Argyropoulou, S. Solujic, D. MuratSpahic, H. Skaltsa, Nat. Prod. Commun. 2010, 5, 1663.

[22] I. Carev, M. Ruščić, M. Skočibušić, A. Maravić, S. Siljak-Yakovlev, O. Politeo, Chem. Biodivers, 2017.

[23] S. Bancheva, J. Greilhuber, Plant Syst Evol, SpringerVerlag, 2006, 257, 95.

[24] J. Vallès, M. A. Canela, S. Garcia, O. Hidalgo, J. Pellicer, I. Sánchez-Jiménez, Caryologia 2013, 66, 221.

[25] S. Siljak-Yakovlev S, M. E. Solic, O. Catrice, S.C. Brown, D. Papes, Plant Biol. 2005, 7, 397.

[26] D. W. Galbraith, K. R. Harkins, J. M. Maddox, N.M. Ayres, D. P. Sharma, E. Firoozabady, Science 1983 220, 1049.

[27] S. Lepers-Andrzejewski, S. Siljak-Yakovlev, S. C. Brown, M. Wong, M. Dron, Am. J. Bot. 2011, 98, 986.

[28] R. P. Adams, Identification of essential oil components by gas chromatography / mass spectrometry. Allured Publ Corp Carol Stream, IL, USA. 4th Ed, 2005.

[29] P. J. Linstrom, W. G. Mallard, NIST Chemistry WebBook, NIST Standard Reference Database Number 69, 2014.

[30] I. F. Benzie, J. J. Strain, Anal. Biochem. 1996, 239, 70.

[31] W. Brand-Williams, M. E. Cuvelier, C. Berset, LWT Food Sci. Technol. 1995, 28, 25.

[32] K. D. Ellman, V. Andres, R. M. Featherstone, Biochem. Pharmacol. 1961, 7, 88.

[33] Clinical and Laboratory Standards Institute, Reference method for broth dilution antifungal susceptibility testing of yeasts; approved standard, CLSI Doc M27-A3. 2008.

[34] Clinical and Laboratory Standards Institute. Reference method for broth dilution antifungal susceptibility testing of filamentous fungi; approved standard. CLSI document M38-A2. CLSI Doc M38-A2. 2008.

[35] Clinical and Laboratory Standards Institute. Performance Standard for Antimicrobial Susceptibility Testing-Approved Standard M100S22. CLSI. 2012.

[36] D. Vidic, M. Maksimović, S. Ćavar, S. Siljak-Yakovlev, Chem. Biodivers 2010, 7, 1208. 
[37] S. U. Savelev, E. J. Okello, E. K. Perry, Phyther Res. 2004, 18, 315.

[38] S. Savelev, E. Okello, N. S. Perry, R. M. Wilkins, E. K Perry, Pharmacol. Biochem. Behav. 2003, 75, 661.

[39] S. Joseph, S. J. Forsythe, Emerg. Infect. Dis. 2011, 17, 1713.

[40] F. Şahin, M. Güllüce, D. Daferera, A. Sökmen, M. Sökmen, M. Polissiou, Food Control 2004, 15, 549.

[41] M. J. Durán-Peña, J. M. Botubol Ares, J. R. Hanson, I. G. Collado, R. Hernández-Galán, Nat Prod Rep. 2015, 32, 1236.
[42] G. P. P. Kamatou, A.M. Viljoen, J. Am. Oil Chem. Soc. 2010, 87, 1

[43] Y. Inoue, T. Hada, A. Shiraishi, K. Hirose, H. Hamashima, S. Kobayashi, American Society for Microbiology 2005, 49, 1770.

[44] C. Q. Sun, C.J. O'Connor, A.M. Roberton, FEMS Immunol. Med. Microbiol. 2003, 36, 9.

[45] N. Ivanova, E.A. Kungulovski Džoko, J. Nat. Sci. Matica Srp. Novi Sad 2013, 124, 171.

[46] T. Marrufo, F. Nazzaro, E. Mancini, F. Fratianni, R. Coppola, L. De Martino, Molecules 2013, 18, 10989. 